\title{
ISOLATION AND STUDY OF A RECOMBINANT CARBOHYDRASE XYLANASE FROM BACILLUS LICHENIFORMIS
}

\author{
Kiribayeva A.K. ${ }^{1,2}$, Mukanov B.A ${ }^{1}$, Baduanova $^{1}$ S.D., Silayev D. ${ }^{1}$., \\ Ramankulov Ye.M ${ }^{1}$, Khassenov B.B. ${ }^{1}$ \\ ${ }^{1}$ National Center for Biotechnology \\ 13/5, Korgalzhyn road, Nur-Sultan, 010000, Kazakhstan \\ ${ }^{2}$ L.N. Gumilyov Eurasian National University \\ Satpayev str., 2, Nur-Sultan, 010000, Kazakhstan \\ asel_january@mail.ru
}

\begin{abstract}
Xylanases are hydrolytic enzymes involved in the degradation of xylan, the main component of plant biomass. In the present study xylanase, XynA, from Kazakh strain Bacillus licheniformis was obtained in recombinant form in Escherichia coli cells. The $x y n A$ gene was amplified from the genomic DNA of the $B$. licheniformis and cloned in pET-28c $(+)$ vector under the control of the promoter of bacteriophage T7. Recombinant XynA was produced in ArcticExpressRP(DE3) cells by plasmid gene expression, protein purification was carried out by metal affinity chromatography. During the study, the dependence of the enzymatic activity of recombinant xylanase on temperature and $\mathrm{pH}$ was observed, it was established that xylanase has the highest activity at $+50^{\circ} \mathrm{C}$ and $\mathrm{pH}$ of 6.9. The activity units at these values of temperature and $\mathrm{pH}$ were 1859 per $\mathrm{ml}$ of purified protein. The working temperature and $\mathrm{pH}$ ranges in which xylanase conserves more than $70 \%$ activity from maximum is $40-60^{\circ} \mathrm{C}$ and $5-8$, respectively.

The data obtained are essential for the use of carbohydrase xylanase from B.licheniformis in biotechnological processes in the processing of vegetable raw materials.
\end{abstract}

Keywords: xylanase, Bacillus, recombinant enzyme, xylanase activity.

\section{INTRODUCTION}

Xylanases (endo-1,4-p-xylanase, EC 3.2.1.8) are enzymes with a molecular weight of 6-80 $\mathrm{kDa}$, which carry out the hydrolysis of $\beta-1,4-x y l o z i d e$ bonds in xylans (hemicelluloses), which is one of the main components plant biomass. The most studied microbial xylanases (from bacteria and fungi), which are involved in the biological degradation of plant biomass and thus play an important role in the cycle of organic carbon in nature [1,2]. Most of the known microbial xylanases belong to the 10th and 11th families of glycoside hydrolases [1].

In industry, xylanases are used for bleaching paper pulp in paper production, to improve the baking properties of flour, the technology of converting vegetable residues, obtaining biologics with prebiotic properties and to increase the nutritional value of feed for farm animals - the processing of cereals, straw, bran.

As it is known, xylan, like cellulose, is not digested by the digestive system of monogastric animals (pigs, poultry, rabbits) and the processing of feed with xylanase increases the content of oligo- and monosaccharides and increases the digestibility of the feed [2]. The literature presents 
data on the use of xylanase for the treatment of grains and cereal crops as part of a complex of enzymes such as cellulose, cellobiohydrolase, catalase, phytase, peroxidase, oxidoreductase, laccase, esterase [3].

\section{Materials and methods}

\section{Strains and plasmids}

In this study Escherichia coli: DH5a, ArcticExpressRP(DE3) strains were used. The bacterial strain Bacillus licheniformis T6 was taken from a laboratory collection (isolated from soil near the city of Taraz).

Plasmid pET-28c(+) (Novagen, UK) was used for cloning and expression.

\section{Oligonucleotides}

In the present work, oligonucleotides sintesized in National Center for Biotechnology were used (table 1).

Table 1. Oligonucleotides

XynA-NcoI 5'-CATGCCATGGCTAGCCCAGACTACTGGCAA-3'

XynA-NotI 5'-TTTTCCTTTTGCGGCCGCCCACACTGTTACGTTAGAACTTC-3'

T7 fw 5'-TAATACGACTCACTATAGGG-3'

T7 rv 5'-TAATACGACTCACTATAGGG-3'

\section{Media}

Luria-Bertani low salt broth was used (1\% tryptone, $0.5 \%$ yeast extract, $0.5 \% \mathrm{NaCl}$ ) for cultivation of E.coli cells. For incubation of the transformed cells, was used SOC medium (2\% tryptone, $0.5 \%$ yeast extract, $0.05 \% \mathrm{NaCl}, 2.5 \mathrm{mM} \mathrm{KCl}, 20 \mathrm{mM} \mathrm{MgSO} 4,20 \mathrm{mM}$ glucose, $\mathrm{pH}$ 7.5). Preparation of media was carried out according to the protocol of Maniatis [4].

\section{Cloning of a xynA gene into the expression vector}

XynA gene was amplified from the DNA of Bacillus licheniformis using primers XynA$\mathrm{NcoI} / \mathrm{Xyn} \mathrm{A}-\mathrm{NotI}$. The amplified gene was inserted in the expression vector pET-28c(+), both digested by NcoI and NotI restriction enzymes. For amplification and cloning, the previously described protocols were used [5]. The presence of the xylanase gene in the transformant strains was confirmed by PCR screening using primers T7 fw/rv. Plasmid DNA hydrolysis, dephosphorylation and ligation were carried out using the enzymes NcoI, NotI, FastAP, T4 DNA ligase and the corresponding buffers for them: Buffer Orange and T4 DNA ligase Buffer manufactured by Thermo Scientific. The nucleotide sequence of the $x y n A$ gene was determined by sequencing using primers $\mathrm{T} 7 \mathrm{fw} / \mathrm{rv}$.

\section{Expression of $x y n A$ gene in E.coli cells}

Competent cells of the E.coli ArcticExpressRP(DE3) strain were transformed by the obtained plasmid vector pXynA by electroporation. The selection of transformants was performed on agar LB medium with kanamycin at a concentration of $50 \mu \mathrm{g} / \mathrm{ml}$. The selected colony-transformant was inoculated to $600 \mathrm{ml}$ of Luria-Bertani broth in the presence of kanamycin and cultured at $37^{\circ} \mathrm{C}$ with shaking $150 \mathrm{rpm}$. Upon reaching an optical density of $\mathrm{OD}_{600}=0.6$, an isopropyl- $\beta$-D-thiogalactopyranoside was added at a final concentration of 0.5 $\mathrm{mM}$. XynA protein induction was performed at $+37^{\circ} \mathrm{C}$ and shaking at $150 \mathrm{rpm}$ for 16 hours.

\section{Purification of recombinant XynA xylanase}

Bacterial cells were centrifugated $\left(6000 \mathrm{~g},+4^{\circ} \mathrm{C}, 7 \mathrm{~min}\right)$ and lysed with lysozyme $(2$ $\mathrm{mg} / \mathrm{ml}$ ), followed by ultrasonic sonication [5]. The XynA protein was isolated from the cell lysate by metal affinity chromatography using $1 \mathrm{~mL}$ HiTrap Chelating (General Electric) column activated with $\mathrm{Ni}^{2+}$ ions. For the creation a linear gradient of the eluate, an AKTA Purifier 10 
FPLC chromatograph (General Electric) was used. Imidazole was used as the eluate at a concentration from 20 to $500 \mathrm{mM}$ with the addition of $500 \mathrm{mM} \mathrm{NaCl}$ in $20 \mathrm{mM}$ Tris- $\mathrm{HCl}(\mathrm{pH}$ 8.0).

\section{Obtaining of xylan}

Crushed beech sawdust was poured with distilled water at the rate of $1 \mathrm{~g}$ of sawdust 40 $\mathrm{ml}$ of water. The mixture was autoclaved at $+121^{\circ} \mathrm{C}$ and a pressure of $1 \mathrm{~atm}, 30$ minutes. The liquid was removed and the alcohol-water extraction was performed. Sawdust was poured with a 1:1 alcohol/water mixture and heated with reflux refrigerator at $+90^{\circ} \mathrm{C}$ for $1 \mathrm{~h}$. The liquid was removed and the sawdust was washed with water and the alcohol-water extraction was repeated for 2 hours. After removing the liquid, the sawdust was washed with water and dried on the filter paper at $+105^{\circ} \mathrm{C}$ for 1 hour. The precipitate was rinsed in a solution of $4 \% \mathrm{NaOH}\left(+18^{\circ} \mathrm{C}\right)$, the resulting suspension was placed on a shaker at $+18^{\circ} \mathrm{C}$ for 6 hours and filtered. The filtrate was neutralized with acetic acid to $\mathrm{pH}$ 5.5-6.5, alcohol was added in a ratio of 1:1 and incubated at $+4^{\circ} \mathrm{C}$ for 16 hours. After, the solution was centrifuged $\left(6000 \mathrm{~g}, 10 \mathrm{~min},+4^{\circ} \mathrm{C}\right)$, the supernatant was removed, and the precipitate was washed three times with cooled $90 \%$ alcohol. The precipitate was dried at a temperature of $+50^{\circ} \mathrm{C}$.

\section{Determination of the dependence of xylanase activity on temperature and $\mathbf{p H}$}

The xylanase activity was determined by the amount of reducing sugars (in terms of xylose) formed from a $1 \%$ xylan solution per unit of time at $\mathrm{pH} 6.5$ and a temperature of $+50^{\circ} \mathrm{C}$ [6].

Determination of the dependence of activity on the temperature in the range from +25 to $80^{\circ} \mathrm{C}$, and on $\mathrm{pH}$ in the range of 2.7-10.2.

\section{RESULTS AND DISCUSSION}

The xylanase gene $x y n A$ was cloned as part of the genetic engineering construct $\mathrm{pET}$ -

$28 \mathrm{c}(+) / \mathrm{Xyn} \mathrm{A}$. In the open reading frame, there is a protein with 197 amino acid residues with deleted signal peptide and a calculated mass of $21.8 \mathrm{kDa}$. The recombinant protein contains a hexahistidine tag at the $\mathrm{C}$-end.

Comparison of the obtained gene sequence with the reference sequence of the xylanase carbohydrase gene from the NCBI database (AF441773.1) showed the presence of 9 nucleotide substitutions, 1 from which leads to amino acids substitution in the target protein: Lys $^{295} \rightarrow$ Tyr $^{295}$.

Figure 1 shows the chromatogram and electrophoregram of XynA protein purification:
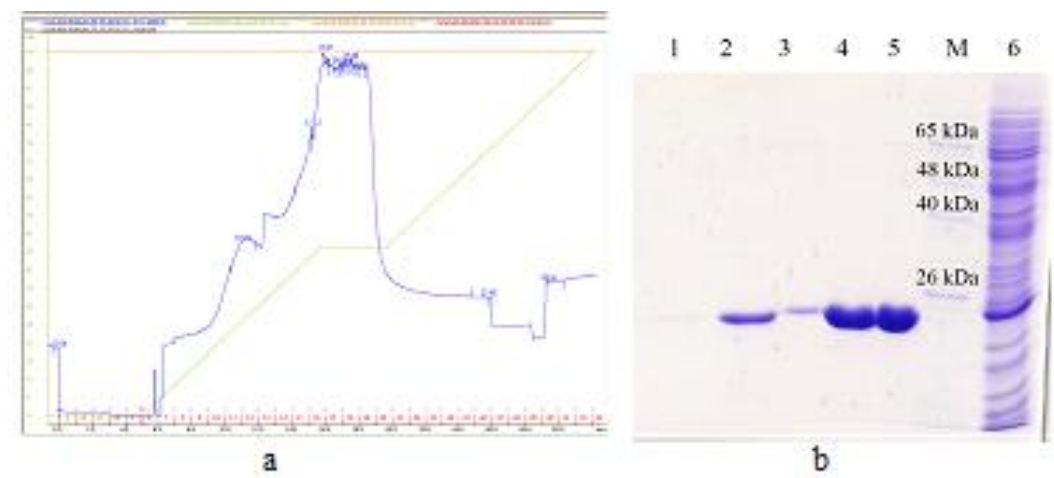

1 -flush the column buffer $20 \mathrm{mM}$ Tris- $\mathrm{HCl}(\mathrm{pH}$ 8,0), $500 \mathrm{mM} \mathrm{NaCl}, 350 \mathrm{mM}$ Imidazole, 2,4,5 chromatographic fractions № 18-20, 3 - chromatographic fraction №21, 6 - load

Fig. 1. The chromatogtam of protein purification XynA (a) and protein electrophoresis fractions (b)

As follows from the figure 1, tagged protein XynA eluted from the column at an imidazole concentration of $232 \mathrm{mM}$. Electrophoresis of the fractions corresponding to the chromatographic 
peak showed that the fractions 19-21 contain xylanase with electrophoretic purity. The concentration of xylanase in fraction 20 is $2 \mathrm{mg} / \mathrm{ml}$.

The xylan obtained from beech sawdust has a powdery form of a light cream shade. In cold water, xylan swells like starch and similar polymers. The yield of xylan was $11 \mathrm{~g}$ from 200 gram of sawdust.

During this study, the dependence of the enzymatic activity of recombinant xylanase from temperature and $\mathrm{pH}$ has shown the highest activity at $+50^{\circ} \mathrm{C}$ and a $\mathrm{pH}$ of 6.9 . The activity at this temperature and $\mathrm{pH}$ was 1859 units per $\mathrm{ml}$ of purified protein. The working temperature and $\mathrm{pH}$ ranges in which xylanase conserves more than $70 \%$ activity is $40-60^{\circ} \mathrm{C}$ and $5-8$, respectively.

\section{CONCLUSION}

Thermal stability of xylanase is an important parameter since high temperatures are used in papermaking, baking and feed manufacturing. Xylanase from the soil bacterium Bacillus licheniformis shows a sufficient level of thermal stability (up to $+50^{\circ} \mathrm{C}$ ) and tolerance to changes in $\mathrm{pH}$ (5-8), which makes this enzyme perspective for industrial application. The maximum activity of recombinant carboxydrase xylanase from B.licheniformis is 930 units/mg.

\section{Acknowledgements}

This work was supported by the Science Committee of the Ministry of Education and Science of the Republic of Kazakhstan (Scientific Technical Program «Creating New Products and Innovative Biotechnologies for Agriculture and Veterinary» under the project «Development of technology for generation of strain producing recombinant carbohydrase»).

\section{REFERENCES}

1. Chakdar H., Kumar M., Pandiyan K., Singh A., Nanjappan K., Kashyap P.L., Srivastava A. K. Bacterial xylanases: biology to biotechnology.3 Biotech., 2016, vol.6, №2, p. 150 .

2. Juturu V., Wu J. C. Microbial xylanases: engineering, production and industrial applications. Biotechnol. Adv., 2012, vol.30, № 6, p.1219-1227.

3. Петриченко В.В., Туманова А.Е. Состав для обработки зерен зерновых, зернобобовых и крупяных культур перед обработкой. Патент РФ RU2605067C1, 2016.

4. Maniatis T., Fritsch E.E. Sambrook J. Molecular cloning. A laboratory manual. New York: Cold Spring Harbor Laboratory, 1982, p.545.

5. Abeldenov S., Kirillov S., Nurmagambetova A., Kiribayeva A., Silayev D., Khassenov B. Expression and purification and biochemical characterization of recombinant phosphohydrolase appa in Esherichia coli. Biotechnology. Theory and Practice, 2014, №3, p. 61-65.

6. Rodrigo P. Nascimento1, Mônica P. Gravina-Oliveira and Rosalie R. R. Coelho. Methods to determine xylanolytic activity. Methods to determine enzyme activity, 2013, chapter 6, p.125-159. 


\title{
BACILLUS LICHENIFORMIS ҚҰРАМЫНАН РЕКОМБИНАНТТЫ КАРБОГИДРАЗА КСИЛАНАЗАНЫ БӨЛІП АЛУ ЖӘНЕ ЗЕРТТЕУ
}

\author{
Кирибаева А.К. ${ }^{1,2}$, Муканов Б.Б. ${ }^{1}$, Бадуанова С.Д. ${ }^{1}$, Силаев Д.В. ${ }^{1}$, \\ Раманқұлов Е.М. ${ }^{1}$, Хасенов Б.Б. ${ }^{1}$ \\ ${ }^{1}$ Ұлттық биотехнология ортальвы \\ Қорвалжын тас жоль, 13/5, Астана қ., 010000, Қазақстан \\ ${ }^{2}$ Л.Н.Гумилев атындагы Еуразия ұлттық университеті \\ Сәтпаев көшесі, 2, Астана к., 010000, Қазақстан \\ asel_january@mail.ru
}

\section{ТYЙІН}

Ксиланазалар өсімдік биомассасының негізгі компоненті болып табылатын ксиланның деградациясына қатысатын гидролитикалық ферменттерді білдіреді. Ұсынылып отырған жұмыста қазақстандық Bacillus licheniformis штаммынан алынған хуnA ксиланазасы E.coli жасушаларында рекомбинантты ақуыз түрінде алынды. ХуnA гені B.licheniformis геномдық ДНҚ-нан амплификацияланып, $T 7$ бактериофагы промоторының бақылауындағы pET-28c (+) векторына клондалды. Рекомбинантты ХуnА ақуызы ArcticExpressRP(DE3) жасушаларында плазмидті экспрессия арқылы алынды, акуыз аффинді хроматография тәсілімен тазаланды. Рекомбинантты ксиланазаның ферментативті белсенділігінің температураға және pH көрсеткіштеріне тәуелділігін зерттеу барысында келесі мәліметтер алынды, ксиланаза $+50^{\circ} \mathrm{C}$ және рН 6,9 көрсеткіштерінде максималды белсендікке ие болады. Температура мен $\mathbf{p H}$ осындай көрсеткіштерінде белсендік сәйкесінше 1859 бірліктерді құрады. Ксиланазаның белсендігінің барынша жоғары көрсеткішін 70\% аса дәрежесінде сақтай алатын жұмыс температурасы мен pH көрсеткіштері $40-60^{\circ} \mathrm{C}$ және 5-8 тең. Алынған деректердің өсімдік материалдарын қайта өндеу кезінде биотехнологиялық үрдістерінде рекомбинантты ксиланаза карбогидразаны пайдалану үшін маңызы зор.

Негізгі сөздер: ксиланаза, Bacillus, рекомбинантты фермент, ксиланазалық белсенділік.

\section{ПОЛУЧЕНИЕ И ИЗУЧЕНИЕ РЕКОМБИНАНТНОЙ КАРБОГИДРАЗЫ} КСИЛАНАЗЫ ИЗ ВАCILLUS LICHENIFORMIS

Кирибаева А.К. ${ }^{1,2}$, Муканов Б.Б. ${ }^{1}$, Бадуанова С.Д. ${ }^{1}$, Силаев Д.В. ${ }^{1}$, Раманкулов Е.М. ${ }^{1}$, Хасенов Б.Б. ${ }^{1}$

${ }^{1}$ Национальный иентр биотехнологии

Кургальжинское шоссе, здание 13/5, Нур-Султан, 010000, Казахстан

${ }^{2}$ Евразийский Национальный Университет им.Л.Н.Гумилева 


\section{АБСТРАКТ}

Ксиланазы представляют собой гидролитические ферменты, участвующие в деградации ксилана, основного компонента растительной биомассы. В представленной работе ксиланаза ХуnA из казахстанского штамма Bacillus licheniformis была получена в рекомбинантной форме в клетках E.coli. Ген xynA был амплифицирован из геномной ДНК бактерии B.licheniformis и клонирован в составе вектора pET-28c (+) под контролем промотора бактериофага Т7. Путем плазмидной экспрессии гена в клетках E.coli ArcticExpress RP(DE3) получали рекомбинантный белок ХуnA, очистка которого проводилась методом металло-аффинной хроматографии. При изучении зависимости ферментативной активности рекомбинантной ксиланазы от температуры и рН было установлено, что ксиланаза имеет максимум активности при $+5^{\circ} \mathrm{C}$ и $\mathrm{pH}$ 6,9. Активность при этих значениях температуры и рН составила 1859 единиц на мл фракции очищенного белка. Диапазон рабочих температур и $\mathbf{p H}$, в которых ксиланаза сохраняет активность более $70 \%$ от максимальной, составляет $40-60^{\circ} \mathrm{C}$ и $5-8$, соответственно. Полученные данные являются существенными для использования рекомбинантной карбогидразы ксиланазы в биотехнологических процессах при переработке растительного сырья.

Ключевые слова: ксиланаза, Bacillus, рекомбинантный фермент, ксиланазная активность 